\title{
Adverse Effects of Fluoride
}

\author{
Abdullatef Nureddin* \\ Department of Oral Surgery, Oral Medicine and oral pathology, Tripoli University, Libya
}

Submission: March 30, 2018; Published: May 11, 2018

*Corresponding author: Abdullatef Nureddin, Department of Oral Surgery, Oral Medicine and oral pathology, Tripoli University, Libya, Tel: 00218914319554; Email: yaema2000@gmail.com

\section{Abstract}

Fluorine is the lightest member of the halogen group and documented as one of the most reactive and electronegative of all chemical substances. It is poisonous, pale, yellowish brown gas. Fluorine does not occur free in nature, therefore, fluorine in the environment is found as fluorides and represent about 0.06-0.09 per cent of the earth's crust. Acute and chronic exposure to excessive oral fluorides has many adverse effects. Therefore, the aim of this review is to bring forward data for dental personal and dental students about fluoride intoxication as fluoride is used excessively in dentistry due to its anti-cariogenic effect.

Keywords: Fluorine; Fluorides; Adverse effect; Anti-cariogenic effect

\section{Introduction}

Fluorides are organic and inorganic compounds containing the element fluorine. The range of fluorine-containing compounds is considerable as fluorine is capable of forming compounds with all the elements except helium and neon. Structurally, fluorinecontaining compounds range from potent toxins such as satin to life-saving pharmaceuticals such as frenzied, and from inner materials such as calcium fluoride to the highly reactive sulfur tetra fluoride. Fluoride-containing compounds are so diverse, inorganic fluoride salts are currently available for human use such as sodium fluoride $(\mathrm{NaF})$, stannous fluoride and sodium monofluorophosphate. Sodium fluoride was first compound used and is the reference standard, it is odorless white powder or in form of crystaline and moderately soluble in water [1,2].

Other fluoride compounds including, fluorosilicic acid $\left(\mathrm{H}_{2} \mathrm{SiF}_{6}\right)$ which is a liquid by product, it is also known as hexafluorosilicic, hydrofluosilicic, and silicofluoric acid that is highly soluble in water. Sodium fluorosilicate $\left(\mathrm{Na}_{2} \mathrm{Sif}_{6}\right)$ is a powder or very fine crystal, also known as sodium silicofluoride that is moderatley soluble in water. Calcium fluoride $\left(\mathrm{CaF}_{2}\right)$ is a colorless solid, relatively insoluble in water as well as in diluted acids and bases. Hydrogen fluoride is a colorless, pungent, acrid liquid or gas that is highly soluble in many organic solvents and in water, in which it forms hydrofluoric acid [2,3]

Soluble fluoride salts, of which sodium fluoride is the most common one, are mildly toxic but have resulted in both accidental and suicidal death from acute poisoning. The minimum fatal dose in human is not known, a case of a fatal poisoning of an adult was reported with 4 grams of $\mathrm{NaF}$, the fatal period ranges from 5 minutes to 12 hours [4].

Complex of aluminum and fluoride (aluminumfluorides, most often $\mathrm{AlF}_{3}$ or $\mathrm{AlF}_{4}$ ) or beryllium and fluoride (beryllofluorides, usually as $\mathrm{BeF}_{3}$ ) occurs when the two elements are present in the same environment. Aluminumfluoride and beryllofluoride complex appear to act analogues of phosphate group-for example, the terminal phosphate of guanidine triphosphate (GPT) or adenosine rtiphosphate (ATP). A number of differen units are commonly used to measure fluoride concentrations in water and biological samples, because the atomic weight of fluorine is 19 , therefore, $1 \mathrm{micro} \mathrm{mol} / \mathrm{L}$ is equal to $0.019 \mathrm{mg} / \mathrm{L}$. Bone ash is typically about $56 \%$ of wet bone by weight, so $1,000 \mathrm{mg} / \mathrm{Kg}$ of fluoride in bone ash is equivalent to about $560 \mathrm{mg} / \mathrm{Kg}$ wet weight [5-8].

\section{Acute and chronic Toxicity}

Symptoms of acute oral fluoride intoxication in humans include sever nausea, vomiting, hypersalivation, abdominal pain, and diarrhea. In severe or fatal cases, these symptoms are followed by convulsions, cardiac arrthymias, and coma. Acute toxic doses range from 1 to $5 \mathrm{mg} / \mathrm{Kg}$. Doses exceeding 15 to $30 \mathrm{mg} / \mathrm{Kg}$ may be fatal. The mechanism of toxicity involves the combination of the fluoride anion with the calcium ions in the blood to form insoluble calcium fluoride, resulting in hypocalcemia; calcium is indispensable for the function of nervous system, and the condition can be fatal. Treatment may involve oral adminstration of dilute calcium hydroxide or calcium chloride to prevent further absorption, and injection of calcium gluconate to increase the calcium level in the blood. Acute effects in experimental animals are similar to those observed in humans, mild gastrointestinal symptoms of acute intoxication may occur at doses as low as $1 \mathrm{mg}$ flouride $/ \mathrm{Kg}$, therefore, fluoride rinses are not recommended for use in children under 6 years of age, since young children usually have inadequate control for their swallowing reflexes [4].

Chronic exposure to excessive fluoride is known to cause dental fluorosis and skeletal fluorosis in humans. Other effects, 
including hypersinsitivity reactions, renal insufficiency, repetitive strain injury, and birth defects. Chronic exposure to fluoride also reported to cause haematological effects such as anemia, eosinophilia, and dysplastic changes on granulocytes in the bone marrow, as well as aquired osteosclerosis, gastrointestinal symptoms, weight loss, lower extremity pain, and sress fractures of the lower extremities [9-12].

\section{Dental Fluorosis}

Several epidemiological studies, begining with those of Dean and co-workers in the 1940's, clearly demonstrated the relationship between dental fluorosis (Yellowish or brownish striations or mottling of enamel) in humans and the level of fluoride in drinking water. Dental fluorosis is a reflection of fluoride exposure only during the time of enamel formation and the degree of fluorosis is dependent on the total fluoride dose, time and duration of fluoride exposure $[13,14]$.

Concentrations of fluoride in drinking water of about 1ppm are associated with a lower incidence of dental fluorosis, particularly in children, whereas excess intake of fluoride in fluoridated water or prolonged use of fluoride supplements, such as fluoride tablets, early use of fluoride tooth paste, another dietary fluoride supplements and prolonged use of infant formula can result in dental fluorosis and lower level of dental caries $[15,16]$.

The first year of life was a significant period for developing dental fluorosis on the mandibular and maxillary central incisors, but there is evidence to suggest that the effects of fluoride resulting in fluorosis prior to eruption of the teeth due to increase fluoride concentration in the extra cellular fluid surrounding the tooth during its development. Furthermore, at the individual level, another factors such as body weight, activity level, nutritional factors, and the rate of skeletal growth and remodeling are also important. Blood group 0 ( $\mathrm{ABO}$ ) phenotypes appeared to be a marker of resistance to fluoride exposure [17-19].

Some studies pointed out that well water had little influence on dental caries experience and is causing dental fluorosis, and the average fluoride concentration among calcified tooth structure decreased in the following order: cementum, dentine and enamel. Enamel fluoride concentrations decreased with increasing depth of enamel where the fluoride content was lowest in the incisal region and highest at the cervical third. The mechanisms that underline the pathogenesis of dental fluorosis are not known but a genetic component may influence an individual's susceptibility or resistance to develop dental fluorosis [19-22].

However, fluoride can be mobilized from the bone adjacent to the enamel organ and result in local fluoride concentrations sufficiently large to adversely affect amelogenesis The target cells for fluoride in chronic fluorosis were shown to be the ameloblasts, the dental pulp cells, and the odontoblasts. Atrophy and necrosis of the ameloblasts were responsible for enamel defects and enamel showed brown discoloration from fluoride depositeds. The odontoblasts were atrophic and the dentine showed brown discoloration $[23,24]$.
However, Enamel is developed by matrix-mediated biomineralization. Crystalines of hydroxyapaptite form a complex protein matrix that serves as a nucleation site. The matrix consists primarily of amelogenin, proteins synthesized by secretory ameloblasts that have a functional role in establishing and maintaining the spacing between enamel crystallites. Full minerlization of enamel occurs when amelogenin fragments are removed from extracellular space. Thus the improper minerlization that occurs with enamel fluorosis is though to be due to inhibition of the matrix proteinase responsible for removing of amelogenin fragments. Therefore, delay in removal impairs crysla growth and makes the enamel more porous. Dental fluorosis appears histopathologically as hypomineralization of the subsurface covered by a well-mineralized outer enamel surface. Other dental defects of excessive fluoride intake including fibrosis of the pulp, alveolar osseous metaplasia, and may delay the eruption of permanent teeth [25-27].

\section{Skeletal Fluorosis}

Endemic skeletal fluorosis is a chronic metabolic bone and joint disease caused by chronic exposure to high doses of fluoride either through water or rarley from foods of endemic areas. The total quantity of ingested fluoride is the single most important factor which determines the clinical course of the disease. Skeletal fluorosis has several stages: two preclinical symptomatic stages characterized by slight radiographically detectable increases in bone mass; early symptomatic stage characterized by sporadic pain and stiffness of joints and osteosclerosis of the pelvis and vertebral column; a second clinical phase associated with chronic joint pain and arthritic symptoms and slight calcification of the ligaments. These features may mimic the diagnosis of seronegative arthritis [28,29].

Crippling skeletal fluorosis characterized by marked limitation of the joint movements, considerable calcification of ligaments, crippling deformaties of the spine and major joints, muscle wasting and neurological defects associated with compressing of the spinal cord. Endemic skeletal fluorosis has been reported predominantly in tropical countries with varying concentrations of fluoride in drinking water. Skeletal fluorosis can also result from prolonged consumption of well water with more than $4 \mathrm{ppm}$ and habitual consumption of large volumes of extra strenght instant black and green tea play an aetiological role in the disease [28-30].

\section{References}

1. Khriachtchev, Pettersson, Runeberg, Lundell, Rasanen (2000) A stable argon compound, Nature 406: 874-876.

2. Sebert JL, Richard P, Mennecier I, Bisset JP, Loeb G (1995) Monofluorophosphate increases lumbar bone density in osteopenic patients: a double-masked randomized study., Osteoporos Int 5(2): 108-114.

3. Reeves TG (1996) Status and strategic plans for fluoridation: Centers for Disease Control and Prevention perspective., J Public Health Dent 56: 242-245.

4. Rabinowitch IM (1945) Acute Fluoride Poisoning. Can Med Assoc J 52(4): 345-349. 


\section{Advances in Dentistry \& Oral Health}

5. Strunecká A, Strunecký O, Patocka J (2002) Fluoride plus aluminum: useful tools in laboratory investigations, but messengers of false information. Physiol Res 51(6): 557-564.

6. Caverzasio J, Palmer G, Bonjour JP (1998) Fluoride: mode of action. Bone 22(6): 585-589.

7. Antonny B, Chabre M (1992) Characterization of the aluminum and beryllium fluoride species which activate transducin. Analysis of the binding and dissociation kinetics. J Biol Chem 267(10): 6710-6718.

8. Rao HV, Beliles RP, Whitford GM, Turner CH (1995) A physiologically based pharmacokinetic model for fluoride uptake by bone. Regul Toxicol Pharmacol 22(1): 30-42.

9. Reddy DR (2009) Neurology of endemic skeletal fluorosis. Neurol India 57(1): 7-12

10. Itai K, Onoda T, Nohara M, Ohsawa M, Tanno K, et al. (2010) Serum ionic fluoride concentrations are related to renal function and menopause status but not to age in a Japanese general population. Clinica Chimica Acta 411(3-4): 263-266.

11. Eren E, Ozturk M, Mumcu EF, Canatan D (2005) Fluorosis and its hematological effects. Toxicol Ind Health 21(10): 255-258.

12. Johnson JEH, Kearns AE, Doran PM, Khoo TK, Wermers RA (2007) Fluoride-related bone disease associated with habitual tea consumption. Mayo Clin Proc 82(6): 719-724.

13. Wongdem JG, Aderinokun GA, Ubom GA, Sridhar MK, Selkur S (2001) Dental fluorosis and fluoride mapping in Langtang town, Nigeria. Afr J Med Med Sci 30(1-2): 31-34

14. Yadav JP, Lata S, Kataria SK, Kumar S (2009) Fluoride distribution in groundwater and survey of dental fluorosis among school children in the villages of the Jhajjar District of Haryana, India., Environ Geochem Health 31(4): 431-438.

15. Cochran JA, Ketley CE, Arnadóttir IB, Fernandes B, Koletsi-Kounari H, et al. (2004) A comparison of the prevalence of fluorosis in 8-yearold children from seven European study sites using a standardized methodology. Community Dent Oral Epidemiol 32(Suppl 1): 28-33.

16. Iida H, Kumar JV (2009) The association between enamel fluorosis and dental caries in U.S. schoolchildren. J Am Dent Assoc 140(7): 855-862.

17. Ismail AI, Messer JG (1996) The risk of fluorosis in students exposed to a higher than optimal concentration of fluoride in well water. J Public Health Dent 56(1): 22-27.

This work is licensed under Creative Commons Attribution 4.0 License DOI: 10.19080/ADOH.2018.08.555746
18. Ellwood RP, Cury JA (2009) How much toothpaste should a child under the age of 6 years use? Eur Arch Paediatr Dent 10(3): 168-174

19. Danilov IP, Protasov VV, Lotosh EA, Luzina FA (2001) [Genetic markers of occupational susceptibility to fluorosis]. Med Tr Prom Ekol 6: 30-33.

20. Ishiguro K, Nakagaki H, Takeuchi K, Mukai M, Yoshika I, et al. (1994) Distribution of fluoride in the dental tissues and their supporting mandibular bone from the same individual. Archives of Oral Biology 39(6): 535-537

21. Koulourides N, Walker A (1979) Fluoride distribution in the facia surfaces of human maxillary central incisors. J Oral Pathol 8: 179-183.

22. Everett ET, McHenry MAK, Reynolds N, Eggertsson H, Sullivan J, et al (2002) Dental fluorosis: variability among different inbred mouse strains. J Dent Res 81(11): 794-798.

23. Angmar Månsson B, Lindh U, Whitford GM (1990) Enamel and dentin fluoride levels and fluorosis following single fluoride doses: a nuclear microprobe study. Caries Res 24(4): 258-262.

24. Bronckers AL, Lyaruu DM, Bervoets TJM, Wöltgens JHM (2002) Fluoride enhances intracellular degradation of amelogenins during secretory phase of amelogenesis of hamster teeth in organ culture. Connect Tissue Res 43(2-3): 456-465.

25. Thylstrup A, Fejerskov O, Mosha HJ (1978) A polarized light and microradiographic study of enamel in human primary teeth from a high fluoride area. Arch Oral Biol 23(5): 373-380.

26. Leroy R, Bogaerts K, Lesaffre E, Declerck D (2003) The effect of fluorides and caries in primary teeth on permanent tooth emergence., Community Dent Oral Epidemiol 31(6): 463-470.

27. Krook L, Maylin GA, Lillie JH, Wallace RS (1983) Dental fluorosis in cattle. Cornell Vet 73(4): 340-362.

28. Gupta R, Kumar AN, Bandhu S, Gupta S (2007) Skeletal fluorosis mimicking seronegative arthritis. Scand J Rheumatol 36(2): 154-155.

29. Whyte MP, Totty WG, Lim VT, Whitford GM (2008) Skeletal fluorosis from instant tea. J Bone Miner Res 23(5): 759-769.

30. Yamaguchi M (2007) Fluoride and bone metabolism. Clin Calcium 17(2): 217-223

\section{Your next submission with Juniper Publishers} will reach you the below assets

- Quality Editorial service

- Swift Peer Review

- Reprints availability

- E-prints Service

- Manuscript Podcast for convenient understanding

- Global attainment for your research

- Manuscript accessibility in different formats

( Pdf, E-pub, Full Text, Audio)

- Unceasing customer service

Track the below URL for one-step submission https://juniperpublishers.com/online-submission.php 